\title{
ОКАЗІОНАЛІЗМИ ЯК ОСНОВА СИНЕРГЕТИКИ ІДІОСТИЛЮ МИКОЛИ ВІНГРАНОВСЬКОГО
}

\author{
ЛАРИСА МІНІЧ \\ Національний університет „Острозька академія”, Острог - Україна \\ larysa.minich@oa.edu.ua; ORCID: 0000-0003-3105-6835

\section{OKAZJONALIZMY JAKO PODSTAWA SYNERGETYKI IDIOSTYLU MYKOŁY WINHRANOWSKIEGO} \\ ŁARYSA MINICZ \\ Uniwersytet Narodowy „Akademia Ostrogska”, Ostróg — Ukraina
}

\begin{abstract}
STRESZCZENIE. Podstawą do stwierdzenia, że słowotwórcze leksemy innowacyjne są powszechne w poezji Mykoły Winhranowskiego jest ich systematyzacja i klasyfikacja. Wśród nich najliczniejszą grupę stanowią leksemy utworzone przez złożenie podstaw; utworzone za pomocą przyrostków jako formantów słowotwórczych; utworzone z wykorzystaniem jednocześnie przedrostków i przyrostków. Rzadko spotykane są neologizmy utworzone za pomocą wyłącznie przedrostków. W niniejszym artykule przedstawiono różne rodzaje okazjonalizmów poety, które autorka analizuje na podstawie wymienionej klasyfikacji. Istotną rolę odgrywa także postawa autorska Winhranowskiego, którą badaczka odbiera jako ważny aspekt psycholingwistyczny w procesie kształtowania indywidualnego stylu twórczego.
\end{abstract}

Słowa kluczowe: synergetyka, lingwosynergetyka, idiostyl, okazjonalizmy, konceptosfera, neologizmy autorskie, innowacje, system leksykalno-semantyczny

\section{OCCASIONALISM AS THE BASIS OF THE SYNERGETICS OF THE IDIOSTYLE OF MYKOLA VINGRANOVSKYI}

\section{LARYSA MINICH}

The National University of Ostrog Academy, Ostrog — Ukraine 
ABSTRACT. The systematization and classification of neolexemes in Mykola Vingranovkyi's poetry prove that the author used them for creating his own literary idiostyle. Among such kinds of words, the most widespread are formed by compounding the stems. The other variants of the poet's words are formed by suffixation and also prefixal-suffixal derivatives. Much less common is to find neologisms formed by only prefixation. In the article, the researcher studies different types of occasional lexemes, analysis of which had been based on the aforementioned classification. In this case, the writer's position is very important. The author shows how the psychoanalytical aspect of the poet's outlook is present in his linguistic presentation of the world.

Keywords: synergetic, linguosynergetic, idiostyle, occasionalism, conceptosphere, author's neologisms, innovations, lexical-semantic system.

$\mathrm{H}$ а сучасному етапі предмет вивчення синергетики (або новітньої загальнонаукової теорії самоорганізації) — дослідження законів та закономірностей глобальної еволюції довільних відкритих, складних систем, головною ознакою яких є нестійкість, нерівноважність та нелінійність. Виникнення цієї науки зумовлене насамперед тим, що системний підхід застосовувався в ході дослідження високоорганізованих матеріальних систем (біологічних, технічних, соціально-економічних), але поза увагою залишалися процеси самоорганізації в цих системах. Результати, що були одержані засновниками синергетики Г. Хакеном та I. Пригожиним, виявились настільки цінними, що це дало змогу поширювати їх на системи довільної природи. У лінгвістиці синергетику розглядають як саморушний процес становлення та виявів синергетичних властивостей концептів у когнітивному просторі художнього тексту, а також з огляду на універсальний та міждисциплінарний характер синергетика виступає методологічним компонентом лінгвокультурологічного дослідження та джерелом породження образності. У цій науковій роботі ставимо за мету проаналізувати оказіоналізми, що становлять основу синергетики ідіостилю М. Вінграновського. Повноцінне дослідження цього лінгвістичного явища неможливе без застосування когнітивно-ономасіологічного та компонентного аналізу.

Синергетичний потенціал творів Миколи Вінграновського багатовекторний, як і визначення самої синергетики, зокрема:

1) синергетика - це явища, які виникають від спільної дії кількох чинників, тоді як кожен окремий чинник не є результатом цієї дії;

2) синергетику трактують як науку про самоорганізацію, тобто ускладнення форми, структури системи при плавній зміні їі параметрів;

3) синергетика — це наука про несподівані явища, поєднання непоєднуваного.

Базуючись на визначенні синергетики, розглянемо оказіоналізми у твоpax М. Вінграновського як причину, яка розкриває синергетичні несподівані поєднання. Проблемою неології на українському мовному грунті займалися 
зокрема Є. А. Карпіловська, Г. М. Вокальчук, С. Я. Срмоленко, Ж. В. Колоїз, А. Стишов, В. В. Максимчук. Великий внесок у теорію оказіонального словотворення зробили Д. Б. Масленников, Т. В. Попова, Е. І. Ханпір, H. I. Фельдман. Появу нових лексичних одиниць у лексичній системі мови традиційно кваліфікують як збагачення, прогрес мови. М. П. Кочерган, вивчаючи історичні зміни словникового складу мови, відзначає чотири типи змін у лексико-семантичній системі: 1) зникнення слів; 2) зникнення значень слів; 3) появу нових слів; 4) появу нових значень [Кочерган 2000: 225].

Проаналізувавши декілька визначень поняття “неологізм”, що подані в різних лінгвістичних джерелах, узагальнимо дефініцію: неологізми (від грец. neos - новий і $\operatorname{logos}$ - слово) - слова, а також їх окремі значення, вислови, які з'явились у мові на певному етапі ії розвитку і новизна яких усвідомлюється мовцями; слова, що були вжиті тільки в якомусь певному акті мовлення, тексті чи мові конкретного автора.

Порушення норми може мати різноманітний характер, виявляючись практично на всіх мовних рівнях. На думку Е. І. Ханпіри, категорія оказіональності може виявлятися також і на будь-якому рівні мовлення. Її прояви — це й оказіональні слова, й оказіональні форми слів, і оказіональні значення слів (тобто вживання відомих слів у значеннях, не властивих їм у мові): кіножиття, листолет, крилечечко, небозвід, бульбохата, дощосіч, вітровінь. Отож, будь-який прояв категорії оказіональності можна назвати оказіоналізмом [Ханпира 1966: 155]. Важливим у понятті “інновація” вважаємо визначення його як певного нововведення, будь-чого нового в мовній системі. Проблемі мовних інновацій велику увагу приділив свого часу Е. Косеріу, який дав їм таке визначення: „усе те, в чому висловлене мовцем (воно розглядається з погляду мовних закономірностей) відхиляється від моделей, що існують у мові, якою ведеться розмова, можна назвати інновацією" [Косериу 1963: 158].

Отже, інновація позначає явища, пов'язані з динамікою мовної системи. Поняття інновації в лінгвістиці родове, тобто охоплює зміни на всіх рівнях мовної системи, узагалі тенденції оновлення мови (зникнення певних одиниць, заміну, появу конкурентних пар і рядів одиниць тощо). На окремих мовних рівнях (морфемному, лексичному, словотвірному, морфологічному, синтаксичному) поняття інновації тлумачиться широко, коли включають не тільки нові слова, створені в системі української мови, але й нові значення наявних слів, морфемо- та словосполуки, афікси, нові лексичні запозичення тощо. До понять “оказіоналізм”, “оказіональність” мовознавці зверталися впродовж тривалого часу. Установлено, що відмінність у визначенні й трактуванні оказіоналізмів можна пояснити різними поглядами дослідників на описуване явище, зокрема О. Чиркова вважає, що оказіоналізми — це слова, які існують у мовленні однієї особи або групи осіб і не мають регулярної відтворюваності в сучасній літературній мові, не зв'язані системними від- 
ношеннями 3 узуальною лексикою, не мають загальноприйнятого значення [Хайдегер 1993: 91]. На думку С. Срмоленко, оказіоналізми - це слова, створені для певного контексту або ситуації, які не потрапляють до словників [Срмоленко 2005:112].

Г. Вокальчук до оказіональних слів зараховує структурно-семантичні новотвори, авторські варіанти загальномовних слів, слова, що за формою збігаються з лексемами, які раніше існували в мові (семантичні новотвори), а також слова, фактично запозичені з інших мов [Вокальчук 2003: 14]. Мовознавці дійшли висновку, що оказіоналізм - це незвичне, експресивно забарвлене слово, яке по-новому, свіжо, оригінально називає предмети, явища дійсності, утворене з відхиленням від законів словотворення чи мовної норми, існує лише в певному контексті, у якому воно виникло, має свого автора і характеризується такими ознаками: належністю до мовлення, утворюваністю, залежністю від контексту, одноразовістю і нерегулярністю використання, ненормативністю, незвичністю і новизною, експресивністю, індивідуальною належністю.

Узагалі, неологізми є невід'ємною частиною пасивної лексики. Розрізняють загальномовні та авторські неологізми. Загальномовні неологізми утворюються, звичайно, для позначення нового предмета чи поняття. Якщо предмет чи поняття закріплені в житті суспільства, то їхня назва з часом перестає сприйматись як нова і переходить до активної лексики. Щодо авторських неологізмів, які називають оказіоналізмами, то вони становлять окрему групу лексичних інновацій. Письменники створюють їх із метою образності і, звичайно, вони не функціонують поза межами твору, у якому вжиті, а з плином часу не втрачають відтінку новизни, зберігають своє експресивне забарвлення.

Основними чинниками, що впливають на появу оказіональних концептів в ідіостилі письменника, є:

1) необхідність дотримання норм силабо-тонічного віршування, зокрема збереження ритміки строфи - М. Вінграновський трансформував узуальний іменник свіm, використавши дещо відмінну за експресивним і стилістичним забарвленням номінацію світище: ... Мій світе, світку, світотенько, Мій світенько, світище мій!.. [Вінграновський 1986: 36];

2) пошуки відповідної (зокрема, більш точної у звуковому відношенні) рими - зокрема замість узуального слова снігопад автор використав його фонетичну і граматичну модифікацію: ...3 далеких берегів $і$ лоз в июю снігопадь лапату приніс від зайия Дід Мороз і дещзо нам у хату [Вінграновський 1986: 124];

3) прагнення надати номінації (і відповідному контекстові) певного стилістичного забарвлення чи відтінку, напр.: ...Коло тебенько я - дивись! Ходять хмари нехмарним небом, по воді сон зорі повивсь біля тебенько, коло тебе [Вінграновський 1986: 59]; 
4) комплексне поєднання кількох зазначених вище чинників - приміром, стилізація контексту під народнопісенне мовлення, пошук необхідної рими і дотримання силабо-тонічних вимог: Бабусин дощ, на клямиі ияпоти, і стежка, і яблуня вже стежкояблуката [Вінграновський 1986: 67].

Новотвори як результат внутрішньомовних процесів мають у потоці нової лексики більшу питому вагу, ніж нові запозичення, особливо результати різних способів морфологічного словотворення: складання слів й основ, афіксації (суфіксації та префіксації), а також безафіксні деривати. Ідеться про словотворення від лексем, уже наявних в українській мові, оскільки словотворення - це процес, який відбувається, на відміну від запозичення, у межах певної мови [Брітікова 2007: 15].

Традиційно неузуальні новотвори (авторські інновації) поділяються на такі типи (за формою одиниці):

1. Фонетичні оказіоналізми, що з'являються в тому випадку, коли автор пропонує специфічний звуковий комплекс, який, на його думку, містить і передає певну семантику, зумовлену фонетичними значеннями звуків - складників цього, так би мовити, новотвору (наприклад, у М. Вінграновського: втеченька-утеча-течія, вечірньосірогусо та ін.). Немає оказіональних одиниць у творчості М. Вінграновського, утворених шляхом фонетичної модифікації. На нашу думку, вони не були цікавими для поета саме тому, що незначна зміна на фонетичному рівні не створювала досконалого нового слова, тоді як словотвірна модифікація поповнювала синергетичний потенціал концептосфери автора.

2. Граматичні (морфологічні) оказіоналізми — це інновації, у котрих у конфлікті перебувають лексична семантика і граматична форма. Тобто це той випадок, коли порушення приписів нормативної граматики сприяє тому, що граматичні форми в поетичній мові можуть набувати естетичної значущості, виразності. До таких найчастотніших випадків формотворення належать індивідуальні форми ступенів порівняння прикметників та прислівників.

3. Лексичні оказіоналізми - це новації, що утворені на основі вже наявних у мові слів за допомогою різних словотворчих засобів - афіксації, композиції основ, абревіації тощо. Такі авторські новотвори, утворені 3 порушенням законів словотвору, мають “непрозору”, більш складну структуру значення (способом складання основ утворені такі новації, як: качачо-гусячий, білоквіт, сериепад, малиновоголово, любомилий, часолет, кіножиття та інші; за допомогою афіксації автор утворив такі оказіональні утворення: піввітру, сосеняточко, ляковище, всепожерний, світище та ін.; у творах М. Вінграновського є також низка новацій, утворених одночасно за допомогою декількох словотвірних засобів (наприклад, стежкояблукатий).

4. Семантичні неологізми, або неосемантизми - це узуальні слова, які в певному контексті набули нового (оказіонального) елементу значення або 
ж втратили один чи кілька компонентів значення, а також у складі структури значення яких відбулося перегрупування сем. До семантичних неологізмів деякі фахівці зараховують також слова та окремі їх значення, утворені внаслідок процесу відродження — актуалізації: гнівань, пліття, ніколиньки, мундироносний.

У поетичному мовленні авторський неологізм уже сам по собі є експресемою - спеціально створеним засобом художньої виразності, одиницею поетичного тексту. Саме тому в будь-якому тексті оказіональні слова — це одні з найбільш яскравих ознак його своєрідності, нестандартності та виразності. Саме на лексичному рівні художня мова найвиразніше виявляе свій образотворчий потенціал. Поетичне слово як своєрідний засіб комунікації $€$ носієм не лише предметно-поняттєвої інформації, а спрямоване насамперед на актуалізацію емоційно-оцінних конотацій, на вербалізацію образно-чуттєвих вражень, уявлень.

Ліриці М. Вінграновського не властиве використання фрази, словосполучення лише для форми чи рими. Кожна його фраза, слово - це концентрований у слові стан душі людини. Індивідуальні концепти — композити та юкстапозити М. Вінграновського - роблять виразними складні номінації, які автор використовує в тексті з метою виокремити унікальність та неповторність кожної миті життя, трансформувати сірі будні у свято, надаючи їм оригінальності. Оказіоналізми М. Вінграновського, утворення яких здебільшого яскраво демонструє дериваційні можливості мови, надають поетичній фразі, слову несподіваної метафоричності, яскравого емоційно-експресивного забарвлення: вечірньосірогусо, перечекаянність, сонцетінь.

Індивідуальні концепти, тобто композити та юкстапозити М. Вінграновського, увиразнюють складні номінації, уведені в контекст з ідейно-естетичною метою - підкреслити унікальність цінність кожної миті життя, надати буденному неповторності. Індивідуально-авторські інновації М. Вінграновського, творення яких здебільшого $є$ реалізацією дериваційних можливостей мови, надають поетичному вислову несподіваної метафоричності, яскравого емоційно-експресивного забарвлення: літатенятонько, всеїжойжучий, дитинно-сіро.

Однією з прикметних рис ідіостилю Миколи Вінграновського є наявність у його творах великої кількості індивідуально-авторських одиниць, які в художньому контексті набувають вагомого експресивно-стилістичного значення. На думку В. Чабаненка, „особлива виразність цих утворень пояснюється їхньою новизною, свіжістю, несподіваністю, а головне - їхньою контрастністю стосовно нормативних лексем" [Чабаненко 2002: 115].

Оказіонально-предметні номінації найбільш інтенсивно поповнюють лексичну систему мови. Цей клас — найбільш репрезентативний, тому широко представлений у творах Миколи Вінграновського. Оказіональні іменники позначені як структурною різноманітністю, так і семантичним розмаїттям. 
Лексичну основу інновацій становлять переважно слова загальнонародного вжитку, нерідко - фольклоризми. Із погляду функцій та, стильового забарвлення серед новотворів поета бачимо художньо-поетичні, книжні, розмовні оказіоналізми, використання яких зумовлене потребами автора надати контекстові певного експресивного забарвлення - ліричного, урочистого, гумористичного, іронічного тощо, напр.: до всіх вминулених страждань, у сизозбурену небопадь, в свосму зорехмарному ряду..., всеӥжоїжучий живіт, Пшоно ти. Згаром-перегаром розвійсь... [Вінграновський 1986: 89, 45, 71].

Більшість основних лексико-граматичних розрядів іменників яскраво представлена у творчому доробку поета. До них належать назви осіб, предметів та явищ дійсності, що являють собою поняття як конкретні, так і абстрактні, як-от:

- назви осіб: скіфеня, товаришочок; з-поміж таких новотворів-іменників вирізняються насамперед назви осіб, які завдяки своїй багатокомпонентності мають значні стилістичні можливості порівняно з простими: бабаюка, niвnримара, холодило;

- назви рослин і їх частин: білоквіт, верболоззя, лілея-дрімолея, дуб-нелинь;

- назви птахів: лелеченятко, ластівенятко, каченя-чапеня;

- назви явищ природи: вітровінь, гриминь, дощосіч, листолет, снігодощ, cнiгопадb;

- назви часових відрізків: всевіч, нощедення, зима-осінь-весна, літо-зимота;

- назви елементів ландшафту: морезвід, вічнотундра, небозвіддя, переяр'я, підзор'я;

- назви абстрактних понять: духоозброєння, дума-принада, сериепад;

- назви фізичних, фізіологічних та психічних станів, почуттів, емоцій: лютіж, любов-лелека, сумовиння, мрійво, гнівань, одинота-одина, перечекаяність, печальність;

- загальні назви географічних об'єктів: гора-мозоль, витребеньочка-ріка, місто-любов;

- назви конкретних предметів: футболик (у значенні м'яч), човниця, бульбохата;

- назви дій, процесів: часолет, перелеття, плинь і т. д.

Переважна більшість зазначених іменників $€$ похідними одиницями, утвореними від основ прикметників та дієслів, з котрими деривати зберігають тісні значеннєві зв'язки: печальний — печальність, лютий — лютіж, білоквітий - білоквіт і т. ін.

Окремо можна вирізнити групу складених предметних номінацій, утворених за допомогою складання декількох основ. Серед інновацій М. Вінграновського можна виокремити такі композити: верболоззя, дощсосіч, листолет, снігодощ, духоозброєння, бульбохата. 
В утворенні лексичних інновацій-юкстапозитів активно використано поєднання двох чи більше компонентів без сполучних голосних, формальну і семантичну цілість яких передає дефіс між ними. Іменники-юкстапозити, виконуючи функцію номінації, складені з компонентів — носіїв обов'язкової невід'ємної ознаки означуваного поняття. Семантику таких лексичних одиниць неможливо розділити на складові компоненти, тому що порушується значення всього слова. Серед цих одиниць переважають лексеми, побудовані 3 двох іменників із дефісним написанням, наприклад: очі-калиновіття, каченя-чапеня, дуб-нелинь, лілея-дрімолея, вітер-лист, втеченька-утеча-течія, поле-колисанка, вітчизна-сльоза-мрія-сон, любов-лелека, світ-сміховиння, місто-любов, гора-мозоль, витребеньочка-ріка, сон-незбуда, одинота-одина, дорога-слід, зима-осінь-вес$н a$, земля-зозуля. Новотвори-юкстапозити в поетичному контексті мають переважно поетичне, урочисте забарвлення. Такі оказіоналізми, часто утворені на основі метафоричного перенесення, являють собою згорнуте порівняння.

Цілком закономірним $є$ той факт, що оказіональний новотвір будь-якого типу повністю реалізовує свою семантику лише в контексті. Адже поза ним новотвір може мати або зовсім інше значення або принаймні не зовсім те, яке хотів розкрити автор, наприклад, авторський неологізм футболик-у значенні м'яч: Телевізор у футболі перепліскує долоні, біла курка кудкудаче, і яєчко, мов футболик, тепло дивиться з гнізда тощо.

Оказіональна експресія може увиразнюватися за допомогою різних стилістичних прийомів - каламбурів, омонімів, паронімів, парономазії, оксиморона, тавтології тощо. Аналіз авторських інновацій у контексті допомагає 3'ясувати їхню стилістичну функцію, глибше зрозуміти причину створення, ступінь письменницької майстерності в галузі творення нових слів. При комплексному вивченні оказіональних мовленнєвих явищ дослідники пропонують ураховувати таку, наприклад, типологію контекстів:

1) нульовий - контекст, у якому оказіоналізм виявляє свою семантику цілком через внутрішню форму, при цьому контекст є ніби надлишковим для семантичної інтерпретації новотвору. Такою самодостатністю характеризуються потенційні слова, утворені за високопродуктивними типами, напр.: білоквіт, верболоззя;

2) контекст найближчого оточення, або міні-контекст (за іншою термінологією - мікроконтекст), — це контекст рядка чи строфи, речення чи абзацу, достатній для з'ясування семантики новотвору, напр.: $i$ mu, темнава птице, не лети із мого серия в летище далеке...;

3) контекст творчості враховується під час дослідження еволюції у використанні автором оказіоналізмів: Здійми мене хоча якесь літатенятонько нешасне...;

4) історико-культурний контекст, або вертикальний контекст, може суттєво допомогти в аналізі семантики новотворів, тобто іноді для з'ясування 
значення інновації необхідні т. зв. фонові знання, що спираються на відому співбесідникам картину ситуації й “загальний фон знань” адресанта й адресата повідомлення: ...І на економічнім небі всеїжӧ̈учий живіт. Саме цей “загальний фон знань” і дозволяє зрозуміти авторські значення новостворених слів. Інакше кажучи, учасники комунікативного дискурсивного діалогу повинні володіти обопільним знанням реалій, що є основою мовного спілкування, зокрема позамовний контекст допомагає глибше проникнути у значення іменникових авторських неологізмів, використаних М. Вінграновським у поезії Шевченко [Вокальчук 2002: 42]. За семантикою авторські номінації неоднорідні, кількість номінацій лексико-семантичних розрядів різна, але номінативна якість та оригінальність кожного неологізму є самодостатнім та унікальним явищем, зокрема інновації - назви істот у М. Вінграновського не $\epsilon$ активно вживаними: скіфеня, дрімайлик, півсмерть, півпримара, що є характерною ознакою ідіостилю М. Вінграновського: Вона ще йшла: півсмерті, півпримари модерним привидом на шиильках між людьми. Обидві номінації - півсмерті, півпримари - означають назви істот й утворені за допомогою префікса пів-.

Авторські оказіоналізми в категорії явищ природи та абстрактних понять представлені значно більшою кількістю концептів. Можна виокремити групу іменників-новотворів, мотивованих дієсловом падати, зокрема: снігопадь, небопад, небопадь (як варіант), сериепад. Інші номінації-іменники мотивовані дієсловом летіти (листолет, часолет): Мій Києве, гайда до неї. Гайда, мій Кисве-листопад... в багряному-сизому інеї, у сизо-збурену небопадь...; Ходімте в сад. Я покажу вам сад, де на колінах яблуні спить вітер. А згорблений чумачький небопад освітлюе пахучі очі квітів.

Окремо можна також згрупувати однокореневі номінації з морфемою сніг-, а саме: снігопадь (пор. з аналогічною номінацією неболадь), снігодощ, сніголет (аналогічно утворені такі авторські неологізми, як часолет, листолет), сніженя та інші: Сміється заєщь з морквою за вухом, зеленим носом ловить сніженя...; Суха та шибка чи волога у сніголет чи в дощосіч, але порожня йде дорога з гори під гору, з ночі в ніч; з далеких берегів і лоз в июю снігопадь лапату приніс від зайия Дід Мороз і дещо нам у хату.

До багатьох номінацій можна дібрати синонімічні сполучення слів, на основі яких створені інновації: білоквіт - білий квіт, всевіч - вся вічність, підзор'яnід зорями, піднеб'я - під небом, середвіття - серед віт і т. ін. Нетрадиційно утворений оказіоналізм многокрилля, оскільки перша частина компонента (много-) не $\epsilon$ нормативною для сучасної української мови: Благословенна світлотінь судьби в щасливім одкровенні, і многокрилля поколінь в однім озоренім іменні.

Отже, інновації - назви явищ природи, які достатньо широко представлені у творчому доробку М. Вінграновського, відзначає високий ступінь новизни. До них належать такі новотвори: дощосіч, звулканення, листолет, 
піввітру, снігодощ, снігопадь, сонщетінь, вітровінь, вітер-лист, втеченька-утеча-течія, зоренятко, хмаренятко, пор.: Суха та шибка чи волога у сніголет чи дощцосіч, але порожня йде дорога з гори під гору, з ночі в ніч; Багряною півчарою схилився в вологих сонцетінях небозвід; і морезвід півчарою другою - і чара зустрічі в руці мойй горить; Обнімає ніч зорю за плечі, синьо посміхається зоря... Ти мені настояна на втечі, Втеченько-утечо-течія...

У поезії XX століття простежуємо закономірне явище: більшість письменників проявляють себе як новатори поетичного слова, результатом чого $\epsilon$ поява численних авторських номінацій. Мову використовують не лише як засіб масової комунікації, а як незамкнену систему мовних знаків, як живий організм, який постійно змінюється, розширюється та поглиблюється.

В індивідуальній концептосфері Миколи Вінграновського найбільш репрезентативною виявляється група іменникових оказіоналізмів. Це є прямим свідченням того, що основний наголос автор робить на номінативній функції новотворів. На другому місці (за кількістю налічуваних одиниць) - розряд номінацій, які представлені відносними прикметниками. Ці закономірності певним чином характеризують синергетику концептосфери М. Вінграновського, його словотворчість, наголошуючи на тому, що процесуальні ознаки були для новатора менш значущими з погляду своєї семантики, ніж ознаки номінативні. На перший план автор виводить об'єкт або суб'єкт мовлення, його властивості та характеристики, а тоді вже звертає увагу на саму дію або процес, який відбувається.

Таким чином, індивідуальні концепти у творчості Миколи Вінграновського, безсумнівно, самодостатні за своєю сутністю. Хоча письменник послуговувався певними принципом щодо творення своїх номінацій, уважаючи, що інформація та енергія $є$ первинними, а матерія, свідомість - похідними, в авторському новотворі семантика, форма слова та енергетична інформація зливаються в одне ціле, відбиваючи загальні закономірності мови, людини, природи і Всесвіту.

\section{Список використаної літератури}

Брітікова К.В., Узуальне та оказіональне в інноваціях сучасної української мови: тенденції оновлення лексико-словотвірної категорії назв особи, дис. ...канд. філол. наук , Харків 2007.

Вокальчук Г.М., До питання про історію дослідження оказіональних лексичних новотворів в украйнському мовознавстві, [в:] „Наук. записки Вінницького держ. педагог. ун-ту ім. М. Коцюбинського. Серія: Філологія”, 2003, вип. 5, с. 14-18.

Вокальчук Г.М., Вивчення неологізмів у вузівському курсі сучасної украӥнської літературної мови, [в:] Збірник наук. праць, 2002, ч. 2, с. 42-48.

Єрмоленко С.Я., Лінгвостилістика: основні поняття, напрями й методи дослідження, [в:] Мовознавство", 2005, № 3-4, с. 112-125. 
Косериу Э., Синхрония, диахрония и история, [в:] „Новое в лингвистике”, Москва, 1963, вып. III, с. 143-343.

Кочерган М.П., Вступ до мовознавства, Київ: Академія, 2000.

Ханпира Э., Об окказиональном слове и окказиональном словообразовании, [в:] „Развитие словообразования современного русского язика", Москва, 1966, с. 153-166.

Чабаненко В., Стилістика експресивних засобів української мови, Запоріжжя, 2002.

\section{Список використаних джерел}

Вінграновський М. С., Вибрані твори., Київ: Дніпро, 1986.

\section{Spysok wykorystanoi literatury [References]}

Britikova K.V., Uzualne ta okazionalne v innovatsiiakh suchasnoi ukrainskoi movy: tendentsii onovlennia leksyko-slovotvirnoi katehorii nazv osoby [The Usual and Occasional Things in the Innovations of Modern Ukrainian Language: the Tendencies of the Person Lexical Word-formative Category Renovation], dys. ...kand. filol. nauk, Kharkiv 2007.

Vokalchuk H.M., Do pytannia pro istoriiu doslidzhennia okazionalnykh leksychnykh novotvoriv $v$ ukrainskomu movoznavstvi [On the Issue of the History of the Researching of Ocassional Word-formations in Ukrainian Linguistic], [v:] "Nauk. zapysky Vinnytskoho derzh. pedahoh. un-tu im. M. Kotsiubynskoho. Seriia: Filolohiia”, 2003, vyp. 5. s. 14-18.

Vokalchuk H.M., Vyvchennia neolohizmiv u vuzivskomu kursi suchasnoi ukrainskoi literaturnoi movy [Study of Neologisms in the University Course of Modern Ukrainian Language], [v:] Zbirnyk nauk. prats, 2002, ch. 2. s. 42-48.

Iermolenko S. Ya., Linhvostylistyka: osnovni poniattia, napriamy y metody doslidzhennia [Linguostylistic: Basic Concepts, Directions and Methods of Research], [v:] „Movoznavstvo”, 2005, № 3-4, s. 112-125.

Koseriu E., Sinkhroniya, diakhroniya i istoriya [Synchrony, Diachrony and History], [v:] „Novoe v lingvistike.” Moskva, 1963, vyp. III, s. 143-343.

Kocherhan M.P., Vstup do movoznavstva [Introduction to Linguistics], Kyiv: Akademiia, 2000. Khanpira E., Ob okkazional'nom slove i okkazional'nom slovoobrazovanii [About the Occasional Word and Occasional Word Formation], [v:] „Razvitie slovoobrazovaniya sovremennogo russkogo yazyka", Moskva, 1966, s. $153-166$.

Chabanenko V., Stylistyka ekspresyvnykh zasobiv ukrainskoi movy [Stylistics of Expressive Means of the Ukrainian Language], Zaporizhzhia, 2002.

\section{Spysok vykorystanykh dzherel \\ [References]}

Vingranovskiy M.S., Vybrani tvory, Kyiv: Dnipro, 1986. 